\title{
La peste bubónica en Chile
}

\author{
ENRIQUE LAVAL R.
}

\section{The bubonic plague in Chile}

A fines de 1899 hizo su aparición la peste bubónica por primera vez en tierra americana. La epidemia se inició en Asunción y Santos, extendiéndose en forma brusca, a principios de 1900, a Rosario, Santa Fe, Buenos Aires y Río de Janeiro.

El Gobierno, por sugerencia del Consejo Superior de Higiene, envió una comisión médica a la República Argentina, presidida por don Alejandro Del Río para estudiar su origen, marcha y características. Su versación en los problemas sanitarios y sus condiciones de organizador se impusieron a las autoridades de Rosario. Con incansable actividad y técnica irreprochable, cooperó a las tareas de saneamiento, en las cuales tuvo tan franco éxito, que las autoridades argentinas no vacilaron en reconocerlo, al rendirle un homenaje público de agradecimiento

Temeroso de que la epidemia pudiese aparecer en Chile, publicó en 1901 su trabajo "La peste bubónica", considerado entonces como un modelo de cartilla sanitaria.

En mayo de 1903, estalló en Iquique una epidemia cuyos caracteres no permitían individualizarla con exactitud. La enfermedad y la alarma cundían, y las autoridades locales se manifestaban incapaces de adoptar medidas que limitaran el mal y llevasen la tranquilidad a los ánimos fuertemente sacudidos por la amenaza. El 29 de ese mes, el Ministerio del Interior designó una comisión presidida por el doctor Del Río e integrada por los doctores Ramón Zegers, Ricardo Dávila Boza y Luis Montero para que "proceda a determinar la naturaleza de la enfermedad aparecida en esa ciudad y se haga cargo de la profilaxia de ella en caso que resultase contagiosa"4. El diagnóstico se formuló rápidamente: era peste bubónica.

La comisión había llegado a Iquique el 1 de junio en la mañana, y al día siguiente había tenido la oportunidad de efectuar la primera autopsia. El 4 de junio, el doctor Zegers, "en un plazo brevísimo y en forma irreprochable" comprobó que se trataba de peste bubónica, lo que se puso de inmediato en conocimiento del Gobierno.

Se produjeron 75 casos y el primero se comprobó el 25 de mayo. De los primeros ocho enfermos sólo sobrevivió uno y a los pocos días de acción sanitaria la enfermedad quedaba yugulada ${ }^{3}$.

Según recuerda Darío Osses, "esta peste llegó a nuestras costas a bordo del vapor Colombia procedente de San Francisco. Se presume que las ratas portadoras del mal subieron en el Callao y desembarcaron en Iquique y Valparaíso"2.

En efecto, la peste bubónica se presentó por primera vez en el Perú en los últimos días de abril de 1903, en el Callao y en Pisco, con una epizootia previa en las ratas encontrándose muchas de ellas enfermas y muertas sobre todo en el Molino Santa Rosa del Callao. Entre el 28 de abril y el 8 de mayo enfermaron diez trabajadores de ese establecimiento, de los cuales fallecieron seis.

Poco después publicaba el doctor Del Río en colaboración con los doctores Zegers, Dávila y Montero, el informe sobre la epidemia de peste bubónica en Iquique en 1903, presentado al supremo Gobierno por la comisión encargada de reconocer la naturaleza de la enfermedad y organizar su profilaxis.

A fines de 1903, la peste bubónica había aparecido en Valparaíso. Se preveía una rápida diseminación en vista de las deplorables condiciones higiénicas del puerto y se temía fundadamente su propagación a la capital. Una vez más el doctor Del Río fue encargado de preparar un completo plan para defender Santiago de la enfermedad, realizándolo con disposiciones tan perfectas que se pudo evitar en esa ocasión, el estallido de la peste bubónica en la ciudad.

La confirmación bacteriológica de la enfermedad en Valparaíso estuvo a cargo del doctor Marmeto Cádiz Calvo quien con motivo del traslado del doctor Alejandro Del Río a Iquique asumió la Cátedra de Higiene como suplente y al renunciar al titular fue nombrado en este carácter el 28 de julio de 1906 y la profeso hasta 1928.

"Otras epidemias amagaron nuestro territorio en distintas épocas. Algunas lo hicieron en áreas reducidas, como fue el caso de la peste bubónica -anota Darío Osses- que en la Edad Media cobro carácter apocalíptico al exterminar la tercera parte de la población europea".

Si bien el año crucial de la peste bubónica en Chile fue 1903, con el brote de Iquique, hubo de lamentarse la aparición de nuevos focos en dicha ciudad, así como en Anca en 1907, correspondiéndole una labor destacada e importante al doctor Ricardo Dávila Boza, quien estuvo permanentemente preocupado de la producción de nuevos casos que se detectaron en Valparaíso, Viña del Mar y Santiago, entre aquel año y 1916. Incluso, cuando se comprobó la enfermedad por vez primera en Iquique, el doctor Dávila evacuó un Informe sobre ubicación de un lazareto para pestosos en Santiago" "5-10.

Así se fue terminando paulatinamente el problema de la peste bubónica en Chile, pasando a ser sólo un recuerdo casi anecdótico en la historia de las enfermedades infecciosas de nuestra patria. 
La última noticia que se tuvo en el país de esta afección fue en 1941, cuando los doctores Abraham Horwitz, Roque Kraljevic, José Perroni y Nicolás Muñoz, comunicaron a la Sociedad Médica de Santiago, "un caso de peste bubónica de forma septicémica, enfermedad que desde hacía 10 años no se presentaba en nuestro país".

\section{Bibliografía}

1.- Laval M E. Don Alejandro Del Río. Rev. Asist. Social 1944; 13: 135.

2.- Osses D. La historia infausta. Vida Médica. 1987: 39: 6.

3.- Laval M E. Doctor Mamerto Cádiz Calvo. En: Noticias sobre los médicos en Chile. Tomo II. Ed. Historia Médica. Santiago de Chile. 1972.

4.- Dávila B R. Informe sobre la epidemia de peste bubónica en Iquique en 1903.
5.- Dávila B R. Informe sobre ubicación de un lazareto para pestosos en Santiago. Rev Ch Hig 1903; 9: 386.

6.- Dávila B R. La peste bubónica en Viña del Mar. Rev Ch Hig 1907; 13: 271.

7.- Dávila B R. La peste bubónica en 1907. Rev Ch Hig 1908; 15: 101.

8.- Dávila B R. La peste bubónica en 1908. Rev Ch Hig 1909; 15: 245.

9.- Dávila B R. La peste bubónica en 1909. Rev Ch Hig 1910; 16: 236.

10.- Dávila B R. La peste bubónica en Santiago y Valparaíso. Rev Ch Hig 1916; 22: 69.

11.- Horwitz A, Kraljevic R, Perroni J, Muñoz N. Sobre un caso de peste bubónica de forma septicémica. Rev Méd Chile 1941: 69: 62.

12.- Artola M R, Arce J, Lavorería D E. La peste bubónica. Informe presentado a la Academia de Medicina. lmp. Torres Aguirre. Lima. Perú. 1903.

13.- Torrechio D. Hechos de Chile. Imp. Soc. Filatélica. Stgo, Chile. 1983. 